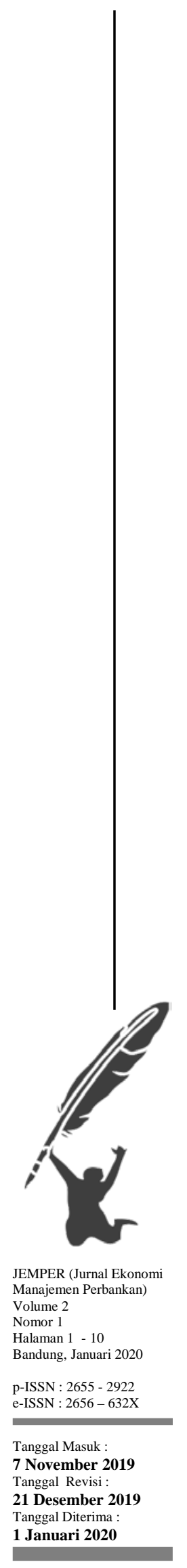

JEMPER(Jurnal Ekonomi Manajemen Perbankan)

http://jurnal.usbypkp.ac.id/index.php/jemper

\title{
PENGARUH KURS DAN PRODUK DOMESTIK BRUTO TERHADAP NERACA TRANSAKSI BERJALAN MELALUI PENDEKATAN ERROR CORRECTION MODEL (ECM)
}

\author{
Ina Namora Putri Siregar ${ }^{1}$ \\ Universitas Prima Indonesia Medan \\ inanamoraputri@gmail.com \\ Fuji Astuty ${ }^{2}$ \\ Universitas Prima Indonesia Medan \\ fujiastuty424@gmail.com
}

\begin{abstract}
The current account balance has increased compared to previous years, but the increase looks slow. So it is feared in global developments, especially those that could pose risks to the overall balance of payments. This study aims to provide empirical evidence about the factors affecting the current account which include the exchange rate and Gross Domestic Product. The current account balance is used to assess external economic stability in Indonesia. This research method uses a quantitative approach. And the data used are time series data from 1997 to 2017 using eviews 9. The model used is multiple linear regression model. The analysis was conducted in a shortterm effect using Ordinary Least Square analysis techniques and Error Correction Mechanism. The results showed that the exchange rate had a positive and not significant effect, while the gross domestic product was significant.
\end{abstract}

Keywords : Current Account Balance, Kurs, Gross Domestic Product and Error Correction Mode

\begin{abstract}
Abstrak
Neraca transaksi berjalan meningkat dibandingkan dengan tahun-tahun sebelumnya, namun peningkatannya terlihat lambat. Sehingga dikhawatirkan dalam perkembangan global, terutama yang dapat menimbulkan risiko pada keseluruhan neraca pembayaran. Penelitian ini bertujuan untuk memberikan bukti empiris tentang faktor-faktor yang mempengaruhi transaksi berjalan yang meliputi nilai tukar dan Produk Domestik Bruto. Neraca transaksi berjalan digunakan untuk menilai stabilitas eksternal ekonomi di Indonesia. Metode penelitian ini menggunakan pendekatan kuantitatif. Dan data yang digunakan adalah data deret waktu dari periode 1997 hingga 2017 dengan menggunakan eviews 9. Model yang digunakan adalah model regresi linier berganda. Analisis dilakukan dalam efek jangka pendek menggunakan teknik analisis Ordinary Least Square dan Error Correction Mechanism. Hasil penelitian menunjukkan bahwa nilai tukar berpengaruh positif dan tidak signifikan, sedangkan produk domestik bruto signifikan.dari negatif.
\end{abstract}

Kata Kunci : Neraca Transaksi Berjalan, Kurs, Produk Domestik Bruto dan Mode Koreksi Kesalahan 


\section{PENDAHULUAN}

Perdagangan internasional memiliki pengaruh pada perekonomian bahkan terhadap seluruh sendi kehidupan bagi Indonesia. Salah satu ciri kegiatan perdagangan internasional adalah adanya ekspor dan impor dimana kegiatan ini tercatat di dalam neraca transaksi berjalan dan merupakan salah satu komponen dari neraca pembayaran. Neraca transaksi berjalan merupakan salah satu indikator penting dalam menunjukkan performance makroekonomi suatu negara dari sisi eksternal, yang juga merupakan cerminan dari perekonomian internal, seperti ekspor dan impor di sektor riil, serta penerimaan dan pengeluaran di sektor fiskal (pemerintah). Neraca transaksi berjalan yang positif (surplus) mencerminkan bahwa negara tersebut meminjamkan kelebihan tabungannya ke luar negeri, sehingga stok net aset bertambah, sedangkan neraca transaksi berjalan yang negatif (defisit) mengimplikasikan negara tersebut kekurangan dana tabungan untuk investasi domestik, sehingga harus meminjam / berutang ke negara lain (Asmarani, 2015)

Hal ini dikarenakan apabila terjadi defisit secara terus menerus pada neraca transaksi berjalan akan mengganggu stabilitas perekonomian Indonesia. Pemerintah mengintervensi untuk membantu menstabilkan neraca transaksi berjalan melalui kebijakan moneter. Kebijakan moneter berupa tindakan pemerintah (melalui Bank Indonesia) untuk mempengaruhi situasi makro yang dilaksanakan melalui pasar uang, dengan cara mempengaruhi kebijakan nilai tukar dan tingkat bunga yang berlaku di pasar uang,(Saputra \& Maryatmo, 2016).

Sehingga defisit neraca transaksi berjalan dapat diatasi melalui peningkatan ekspor dan mengurangi impor. Adapun perkembangan neraca transaksi berjalan dapat dilihat dari tabel berikut :

Tabel 1

Neraca Transaksi Berjalan Periode 2013 - 2017

\begin{tabular}{lll}
\hline Tahun & $\begin{array}{c}\text { Neraca Transaksi Berjalan } \\
\text { (Juta USD) }\end{array}$ \\
\hline $\mathbf{2 0 1 3}$ & - & 29.109 \\
$\mathbf{2 0 1 4}$ & - & 27.510 \\
$\mathbf{2 0 1 5}$ & - & 17.519 \\
$\mathbf{2 0 1 6}$ & - & 16.952 \\
$\mathbf{2 0 1 7}$ & - & 16.196 \\
\hline
\end{tabular}

Sumber : Data diolah dengan Eviews

Dari Tabel 1 menunjukkan tahun 2017, neraca transaksi berjalan masih mengalami defisit meskipun lebih baik bila dibandingkan defisit tahun sebelumnya. Perubahan kondisi defisit transaksi berjalan ini dikarenakan adanya peningkatan dari surplus neraca perdagangan nonmigas. Namun, masih terdapat defisit karena impor migas terjadi peningkatan. Diantaranya sektor transportasi dan neraca pendapatan primer untuk pembayaran repatriasi dari hasil investasi asing. Sedangkan di kuartal IV masih mengalami defisit. Hal ini dikarenakan menurunnya surplus neraca perdagangan barang dan peningkatan defisit neraca jasa. Kondisi ini bersumber dari kenaikan impor, disertai menguatnya kebutuhan berinvestasi dan kegiatan produksi yang melampaui dari kenaikan ekspor. Meskipun neraca transaksi berjalan mengalami peningkatan dibandingkan dengan tahun-tahun sebelumnya, namun peningkatannya terlihat lambat. Bila ini terjadi seperti ini dikhawatirkan dalam perkembangan global, khususnya yang dapat memberikan risiko bagi kinerja neraca pembayaran secara keseluruhan antara lain terkait normalisasi kebijakan moneter di beberapa negara maju, tekanan geopolitik di beberapa kawasan serta naiknya harga minyak dunia.

Dengan demikian neraca transaksi berjalan sangat penting artinya bagi suatu negara. Melalui transaksi berjalan dapat memberikan gambaran keadaan perekonomian suatu 
negara. Selain itu, nilai defisitnya neraca transaksi berjalan dapat menimbulkan krisis negara yang bersangkutan. Oleh karena itu sangatlah penting bagi para ekonom dalam memperhatikan perkembangan transaksi berjalan dan faktor-faktor yang mempengaruhinya. Banyak faktor yang mempengaruhi neraca transaksi berjalan, salah satunya adalah faktor makroekonomi. Semakin baik dan stabil kondisi makroekonomi maka diharapkan neraca transaksi berjalan akan semakin surplus yang juga pada akhirnya akan mempengaruhi neraca pembayaran suatu negara. (Wijaya, 2019)

Salah satu yang mempengaruhi neraca transaksi berjalan adalah nilai tukar. Pada saat nilai tukar rupiah terhadap dolar AS mengalami depresiasi, berarti terjadi penurunan nilai mata uang rupiah. Hal ini menyebabkan naiknya harga barang luar negeri atau harga barang dalam negeri lebih murah, dalam hal ini maka sebuah negara akan mengurangi kegiatan impor, neraca transaksi berjalan akan menjadi surplus. Begitu pula sebaliknya, jika rupiah mengalami apresiasi, maka harga barang luar negeri relative lebih murah ketimbang harga barang dalam negeri. Hal ini membuat impor lebih dominan ketimbang ekspor. Kelebihan impor inilah yang menyebabkan defisit neraca transaksi berjalan. (Amzar2, 2017)

Menurut (Ariyani, Priyanto, \& Yuliati, 2018) bahwa Otoritas moneter dituntut untuk memperkuat operasi moneter untuk mendukung stabilisasi nilai tukar dan kontrol likuiditas, dan meningkatkan peninjauan mata uang asing untuk mengendalikan defisit neraca transaksi berjalan.

Dilihat dari keterkaitan antara variabel-variabel yang mempengaruhi neraca transaksi berjalan akan menunjukkan semakin pentingnya sinkronisasi dalam kebijakan ekonomi sehingga dapat memperbaiki kinerja neraca transaksi berjalan. Bank Indonesia memiliki wewenang dalam kebijakan moneter (BI rate) dan kebijakan stabilisasi nilai tukar harus memperhatikan bagaimana dampaknya terhadap sektor riil (Handoko, 2015).

Selain kurs, yang dapat mempengaruhi neraca transaksi berjalan yaitu produk domestik bruto. Produk Domestik Bruto menggambarkan suatu kondisi pertumbuhan perekonomian negara. Hal ini dikarenakan Produk domestik bruto menunjukkan suatu kemampuan konsumen domestik dalam membeli barang-barang konsumsi. Maka, bila produk domestik bruto mengalami peningkatan akan menyebabkan peningkatan belanja masyarakat terhadap barang-barang, termasuk barang impor suatu negara. Sehingga hal itu dapat memperburuk kondisi neraca transaksi berjalan. Sebaliknya, apabila produk domestik bruto mengalami penurunan yang akan menimbulkan belanja barang-barang termasuk barang impor suatu negara akan mengalami penurunan.

Penelitian (Ariyani et al., 2018) bahwa nilai variabel kurs mempunyai pengaruh negatif dan signifikan dalam jangka panjang pada neraca transaksi di 6 (enam) negara ASEAN. Sedangkan produk domestik bruto, tingkat suku bunga dan investasi asing langsung mempunyai pengaruh negatif dan signifikan dalam jangka panjang pada neraca transaksi di 6 (enam) negara ASEAN.

Penelitian (Hung \& Gamber, 2010), bahwa kemampuan proyeksi pendekatan absorption menggungguli pendekatan elasticity. Tiga variabel yang secara signifikan berpengaruh negatif terhadap neraca transaksi berjalan adalah nilai tukar riil, pertumbuhan ekonomi AS, dan kekayaan swasta. Sementara itu, variabel pertumbuhan mitra dagang AS dan anggaran belanja AS berpengaruh positif terhadap neraca transaksi berjalan.

Sedangkan menurut (Fazil KAYIKÇI, 2012) dalam penelitiannya bahwa pertumbuhan PDB, investasi, harga minyak dan nilai tukar riil berdampak negatif terhadap neraca transaksi berjalan sedangkan inflasi dan tabungan berdampak positif.

(Clower \& Ito, 2012) mengungkapkan bahwa derajat keterbukaan ekonomi, net foreign assets dan pembangunan sektor finansial berpengaruh positif terhadap neraca transaksi berjalan pada sebagian besar negara. Dengan demikikan rezim nilai tukar bukanlah faktor utama terhadap persistensi neraca transaksi berjalan, melainkan rezim fixed exchange rate 
lebih berpengaruh membuat negara berkembang memiliki neraca transaksi berjalan yang fluktuatif.

\section{LITERATUR}

Neraca transaksi berjalan atau current account merupakan neraca yang meliputi perdagangan barang dan jasa, penghasilan (income), serta transfer berjalan (current transfer). Umumnya neraca transaksi berjalan menggambarkan nilai bersih antara sisi debit dan kredit dari seluruh transaksi yang tercatat dalam setiap komponen transaksi berjalan. Transaksi kredit terjadi apabila transaksi tersebut mengakibatkan timbul dan bertambahnya hak penduduk negara yang mempunyai neraca pembayaran internasional untuk menerima pembayaran dari negara lain. Sedangkan debit terjadi apabila transaksi tersebut mengakibatkan timbul dan bertambahnya kewajiban bagi penduduk negara yang mempunyai neraca pembayaran tersebut untuk mengadakan pembayaran kepada penduduk negara lain (Kuncoro, 2015:158). Sedangkan menurut Bank Indonesia (2008) dalam Handoko (2010:3), transaksi berjalan (current account) mengukur penerimaan dan pengeluaran Indonesia yang berasal dari transaksi barang dan jasa (goods and services), pendapatan (income), dan transfer berjalan (current transfer) dengan bukan penduduk.

Ketidakstabilan neraca transaksi berjalan disebabkan oleh beberapa faktor ekonomi makro baik internal maupun eksternal. Adapun kondisi ekonomi makro eksternal yang dapat mempengaruhi transaksi neraca berjalan disebabkan oleh kondisi perekonomian dunia seperti tingkat pendapatan Negara tujuan ekspor dan tingkat harga barang-barang di luar negeri. Sedangkan kondisi ekonomi makro internal yang dapat mempengaruhi transaksi neraca berjalan yaitu tingkat pendapatan nasional, tingkat suku bunga, harga barangbarang dalam negeri dan jumlah uang beredar. Disamping itu, pengaruh kebijakan fiskal dan kebijakan perdagangan juga dapat mempengaruhi neraca transaksi berjalan. (Sakuntala, 2017)

Menurut Triyono (2008), kurs ( Exchange rate) adalah pertukaran antara dua mata uang yang berbeda, yaitu merupakan perbandingan nilai atau harga antara kedua mata uang tersebut. Selain itu kurs merupakan salah satu harga yang lebih penting dalam perekonomian terbuka, karena ditentukan oleh adanya keseimbangan antara permintaan dan penawaran yang terjadi di pasar, mengingat pengaruhnya yang besar bagi neraca berjalan maupun bagi variabel makroekonomi lainnya (Oktavia, dkk, 2013).

Hubungan kurs dengan neraca transaksi berjalan memiliki hubungan yang berkaitan. Menurut Nopirin (2009) apabila karena suatu hal kurs valuta mengalami apresiasi (nilai mata uang asing meningkat dan nilai mata uang lokal menurun), maka hal ini secara relatif dapat menyebabkan rendahnya harga barang ekspor disbanding harga barang impor. Kondisi ini berpengaruh pada meningkatnya kemampuan ekspor dan menurunnya kemampuan impor. Apabila kemampuan ekspor lebih besar daripada kemampuan impor, maka hal ini dapat menyebabkan surplus neraca transaksi berjalan melalui neraca perdagangan. Demikian sebaliknya, oleh karena itu menurut Keynesian dengan asumsi ceteris paribus, hubungan antara kurs valuta dengan neraca transaksi berjalan adalah positif.

Menurut Supriana (2008:17), Produk Domestik Bruto dapat diartikan sebagai barang dan jasa yang diproduksi (dengan menggunakan faktor produksi milik warga negara maupun milik warga negara asing yang ada di negara tersebut) dalam satu negara pada tahun tertentu.

Tingkat bunga merupakan variabel makro ekonomi terakhir yang diduga mempengaruhi neraca transaksi berjalan. Tingkat bunga adalah ukuran investasi yang dapat diperoleh investor dan juga ukuran biaya modal yang harus dikeluarkan oleh perusahaan untuk 
menggunakan dana dari investor. Secara umum, tingkat bunga dibagi menjadi dua jenis, yaitu :

a. Tingkat bunga nominal merupakan tingkat bunga yang tidak memasukkan unsur/dampak inflasi dan tingkat bunga ini langsung dipublikasikan oleh pihak perbankan.

b. Tingkat bunga riil merupakan tingkat bunga yang sudah dikoreksi dengan inflasi. Tingkat bunga ini mencerminkan pendapatan oleh penabung yang sudah menghilangkan dampak perubahan harga. Adapun

Menurut Samuelson, 1985 dalam Saputra dan Maryatmo, 2016 bahwa negara yang mengetatkan kebijakan moneternya cenderung akan menaikan suku domestiknya dengan mengalirnya modal ke dalam negeri maka mata uang negara itu akan mengalami apresiasi dengan akibat merosotnya ekspor neto riil. Kebijakan suku bunga yang mempengaruhi aliran modal nantinya akan berdampak pada perubahan nilai tukar rupiah. Nilai tukar yang terdepresiasi akan menyebabkan harga ekspor menjadi lebih tinggi dan sebaliknya saat nilai tukar terdepresiasi maka harga ekspor lebih rendah. Melalui mekanisme suku bunga dan nilai tukar berfungsi sebagai alat mekanisme penyesuaian neraca transaksi berjalan sehingga neraca pembayaran internasional diharapkan selalu dalam keadaan stabil.

\section{METODE PENELITIAN}

Penelitian ini menggunakan pendekatan kuantitatif dengan metode deskriptif. Jenis data yang digunakan adalah data sekunder yang diperoleh dari website resmi www.bi.go.id, dan www.research.stlouisfed.org yang berbentuk runtun waktu (time series). Metode pengumpulan data adalah metode tidak langsung yaitu dokumentasi.

Teknik analisis data dalam penelitian ini mengacu pada model dasar persamaan regresi linier berganda dengan metode Error Correction Mechanism Engle-Granger (ECM - EG) dalam mengestimasi hubungan jangka pendek antara variabel kurs dan produk domestik bruto dengan neraca transaksi berjalan di Indonesia. Adapun model penelitian menggunakan persamaan regresi linier berganda. Model dasar dalam penelitian ini dapat disusun sebagai berikut :

$\mathrm{CA}=f(\mathrm{E}, \mathrm{PDB})$

$\mathrm{CA}=\beta_{0}+\beta_{1} E+\beta_{2} P D B+\varepsilon i$

Persamaan (2) diubah ke dalam bentuk persamaan logaritma natural sebagai berikut :

$\operatorname{LnCA}=\beta_{0}+\beta_{1} \operatorname{LnE}+\beta_{2} \operatorname{LnPDB}+\varepsilon_{i}$

Dimana : CA adalah Neraca Transaksi Berjalan, E adalah Kurs, PDB adalah Produk Domestik Bruto, Ln adalah Logaritma natural, $\beta_{0}$ adalah Konstanta, $\beta_{1}: \beta_{2}$ adalah Koefisien regresi, $\varepsilon_{\mathrm{i}}$ adalah variabel gangguan (disturbance error).

Model logaritma natural adalah model log-log untuk mengukur elastisitas dari variabel. Salah satu ciri model log-log yang menjadikan model ini menjadi popular dalam penggunaannya adalah koefisien kemiringan $\beta_{1}: \beta_{2}: \beta_{3}: \beta_{4}$ yang mengukur elastisitas $Y$ terhadap $\mathrm{X}$, yaitu persentase perubahan $\mathrm{Y}$ jika terjadi persentase perubahan (kecil) dari $\mathrm{X}$. Jika Y menunjukkan kuantitas permintaan barang dan $X$ adalah unit harga, maka $\beta_{1}: \beta_{2}$ : $\beta_{3}: \beta_{4}$ mengukur elastisitas harga dari permintaan, parameter yang sangat penting dalam ekonomi.

Persamaan model koreksi kesalahan (ECM) - Engle Granger dari persamaan (3) yang akan diestimasi, sehingga dapat ditulis sebagai berikut : 


$$
\begin{aligned}
& \Delta L n C A=\alpha_{0}+\alpha_{1} \Delta L n E+\alpha_{2} \Delta L n P D B+\alpha_{5}\left(\operatorname{LnCA}_{t-1}-\beta_{0}-\beta_{1} L n E_{t-1}\right. \\
& \left.-\beta_{2} \operatorname{LnPDB} t-1\right)+v i
\end{aligned}
$$

atau dapat ditulis menjadi :

$d L n C A=\alpha_{0}+\alpha_{1} d L n E+\alpha_{2} d L n P D B+\alpha_{3} E C T$

Dimana :Ln adalah Logaritma Natural, d adalah First Difference, ECT adalah Error Correction Term, koefisien $\alpha_{1}, \alpha_{2}$, adalah koefisien regresi jangka pendek sedangkan koefisien $\alpha_{3}$ merupakan koefisien koreksi ketidakseimbangan (speed of adjustment).

\section{HASIL DAN PEMBAHASAN}

Hasil Pengecekan Pengujian Stasionaritas Data

\section{Tabel 2}

Hasil Unit Root Test Pada Tingkat Level

\begin{tabular}{ccccc}
\hline No & Variabel & Level & Prob. ADF & Kesimpulan \\
\hline $\mathbf{1}$ & LnCA & Level & 0.5269 & Tidak Stasioner \\
$\mathbf{2}$ & E & Level & 0.2201 & Tidak Stasioner \\
$\mathbf{3}$ & LnPDB & Level & 0.8868 & Tidak Stasioner \\
\hline \multicolumn{4}{l}{ Sumber : Data diolah dengan Eviews }
\end{tabular}

Berdasarkan tabel 2 di atas bahwa hasil empiris dari variabel-variabel menunjukkan tidak ada stasioner di tingkat level. Hal ini dapat dilihat dari probability ADF yang diperoleh lebih besar dari $\alpha=0.05$. Setelah melakukan uji akar unit maka dilakukan uji stasioneritas data dengan melihat data stasioner pada tingkat first difference. Hasil ini dapat dilihat pada tabel 3 berikut ini :

\section{Tabel 3}

Hasil Unit Root Test Pada First Difference

\begin{tabular}{ccccc}
\hline No & \multirow{2}{*}{ Variabel } & Level & Prob. ADF & Kesimpulan \\
\hline $\mathbf{1}$ & $\mathrm{D}(\mathrm{LnCA})$ & First difference & 0.0003 & Stasioner \\
$\mathbf{2}$ & $\mathrm{D}(\mathrm{E})$ & First difference & 0.0005 & Stasioner \\
$\mathbf{3}$ & $\mathrm{D}($ LnPDB) & First difference & 0.0020 & Stasioner \\
\hline
\end{tabular}

Dari tabel 3 menunjukkan bahwa semua variabel stasioner pada first difference. Dan ini dapat dilihat dari probability ADF yang diperoleh lebih kecil dari $\alpha=0.05$.

\section{Hasil Estimasi Persamaan Regresi Linier Berganda (Jangka Panjang)}

Setelah dilakukan uji akar unit melihat variabel sudah stasioner, maka dilakukan estimasi persamaan regresi linier berganda (persamaan jangka panjang) dengan teknik Ordinary Least Square (OLS). Estimasi persamaan ini untuk melihat pengaruh variabel independen terhadap variabel dependen dalam jangka panjang. Hasil empiris yang didapat yaitu :

$\mathrm{LNCA}=74.24991+0.523339 * \mathrm{E}-8.093616 * \mathrm{LNPDB}$

Berdasarkan hasil empiris di atas menunjukkan bahwa dalam jangka panjang variabel nilai tukar ( E ) dan Produk Domestik Bruto (PDB) berpengaruh terhadap neraca transaksi berjalan di Indonesia.

\section{Hasil Pengecekan Pengujian Kointegrasi}

Penelitian ini menggunakan uji kointegrasi Engle-Granger (EG). Uji ini dilakukan terhadap nilai residual atau variabel gangguan dari persamaan (1). Dari hasil estimasi 
bahwa nilai ADF statistik -4.674842> nilai kritis $\alpha=5 \%(-3.020686)$ dengan nilai probability $0.0016<\alpha=0.05$. Sehingga menunjukkan bahwa variabel saling berkointegrasi atau mempunyai hubungan jangka panjang.

\section{Hasil Estimasi Persamaan Jangka Pendek (Error Correction Mechanism)}

Untuk melakukan koreksi dari ketidakseimbangan yang terjadi dalam jangka pendek dengan memasukkan nilai penyesuaian (adjustment) menuju pada keseimbangan jangka panjang, untuk itu dilakukan estimasi model ECM dari persamaan (5) dan diperoleh hasil empiris berikut :

$\mathrm{D}(\mathrm{LNCA})=0.932248+0.274263 * \mathrm{D}(\mathrm{E})-8.198015 * \mathrm{D}(\mathrm{LNPDB})-0.718967 * \mathrm{ECT}(-$ 1).................................(6)

Berdasarkan hasil empiris dari persamaan (6) dapat diinterpretasikan bahwa nilai koefisien koreksi ketidakseimbangan atau speed of adjustment memiliki tanda nilai negatif dan signifikan secara statistik dengan probabilitas ECT 0.0016<0.05. Maka model ECM yang digunakan telah valid (tepat) untuk dipilih menjadi model empirik.

Nilai koefisien dari ECT (speed of adjustment) sebesar 0.718967 menunjukkan bahwa ada sebesar 71.89\% ketidakseimbangan pada pengaruh jangka pendek perubahan variabel nilai tukar dan produk domestik bruto terhadap neraca transaksi berjalan di Indonesia.

Kenaikan kurs (E) sebesar 1 satuan akan menyebabkan kenaikan neraca transaksi berjalan di Indonesia sebesar 0.274263 satuan.

Penurunan produk domestik bruto (PDB) sebesar 1 satuan akan menyebabkan penurunan neraca transaksi berjalan di Indonesia sebesar 8.198015 satuan.

\section{Hasil Pengecekan Pengujian Asumsi Klasik}

Untuk pengecekan asumsi klasik diperlukan semua metode yang menggunakan regresi dalam proses analisisnya. Dengan demikian uji asumsi klasik yang dilakukan dalam penelitian ini adalah uji normalitas, uji multikolinieritas, dan uji autokorelasi.

\section{Hasil Uji Normalitas}

Penggunaan uji normalitas dapat mengetahui apakah residual dari data penelitian berdistribusi normal atau tidak. Penelitian ini menggunakan Uji Jarque - Berra (J-B test). Hasil empiris uji normalitas dapat dilihat pada gambar 1 berikut ini :

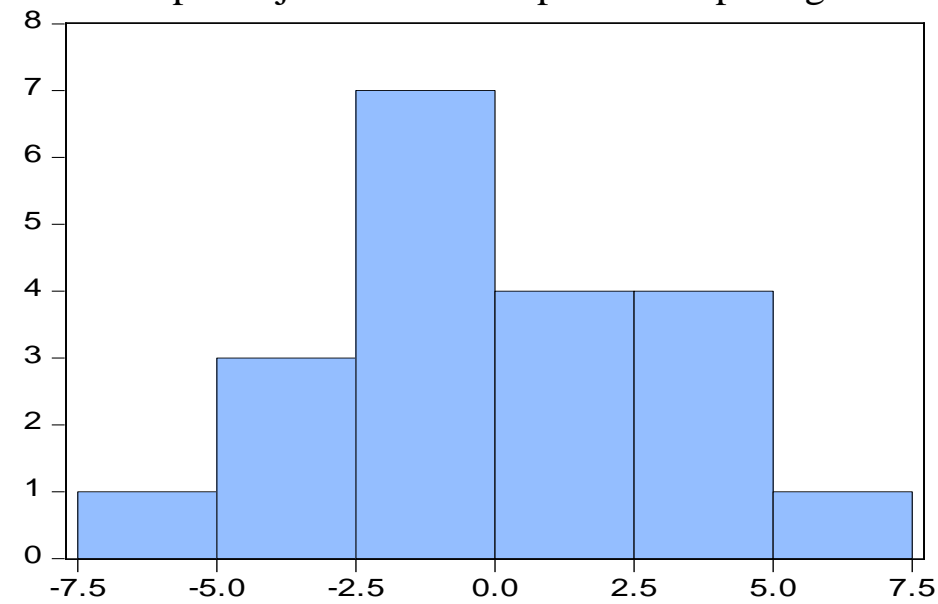

$\begin{array}{lc}\text { Series: Residuals } \\ \text { Sample 1998 } 2017 \\ \text { Observations } 20 \\ \text { Mean } & -3.55 e-16 \\ \text { Median } & -0.490295 \\ \text { Maximum } & 6.930803 \\ \text { Minimum } & -7.344748 \\ \text { Std. Dev. } & 3.383232 \\ \text { Skewness } & 0.043371 \\ \text { Kurtosis } & 2.830031 \\ & \\ \text { Jarque-Bera } & 0.030345 \\ \text { Probability } & 0.984942\end{array}$

Gambar 1

Histogram dan Statistik Residual dari Uji Jarque-Bera

Sumber : Data diolah (Eviews) 
Berdasarkan hasil uji normalitas pada gambar 1 menunjukkan bahwa nilai statistik JB-test dengan angka probability $0.984942>\alpha=0.05$ dapat disimpulkan tidak signifikan, hal ini berarti menerima hipotesis dan bahwa residual atau faktor penggangu telah berdistribusi normal.

\section{Hasil Uji Multikolinieritas}

\section{Tabel 4}

Hasil Uji Korelasi Variabel-Variabel Independen

\begin{tabular}{lll}
\hline Variabel & D(E) & D(LNPDB) \\
\hline D(E) & 1.000000 & 0.355067 \\
D(LNPDB) & 0.355067 & 1.000000 \\
\hline
\end{tabular}

Sumber : Data diolah (Eviews)

Berdasarkan tabel 4 bahwa nilai koefisien korelasi (r2) antar variabel bebas tidak ada yang memiliki nilai melebihi 0.9. Namun, untuk lebih memastikan dapat dilakukan uji berikutnya dengan menggunakan metode Variance Inflation Factor (VIF) dari nilai korelasi pada tabel 5.4 di atas.

\section{Tabel 5}

\begin{tabular}{|c|c|c|}
\hline Variabel & $\mathbf{D}(\mathbf{E})$ & D(LNPDB) \\
\hline $\mathbf{D}(\mathrm{E})$ & 1.000000 & 1.14426 \\
\hline D(LNPDB) & 1.14426 & 1.000000 \\
\hline
\end{tabular}

Dilihat dari hasil empiris tabel 5 bahwa nilai VIF dari korelasi variabel-variabel bebas tidak ada yang melebihi angka 10. Maka dapat disimpulkan bahwa antar variabel bebas tidak terjadi multikolinieritas.

\section{Hasil Uji Autokorelasi}

Nilai Durbin Watson (DW) statistk sebesar 1.524426 pada persamaan model ECM (jangka pendek). Uji autokorelasi dengan metode DW yaitu membandingkan nilai DW statistik dengan DW tabel. Jika nilai DW statistik terletak di daerah tidak ada autokorelasi berarti memenuhi asumsi klasik regresi. Untuk mengetahui posisi tersebut dengan mencari nilai du dan dl dari tabel DW. Dalam penelitian ini jumlah sampel $n=21$ dan jumlah variabel $\mathrm{k}=2$, nilai $\mathrm{dl}=1.125$ dan nilai du $=1,538$.

Dari hasil empiris nilai DW hitung berada di daerah tidak dapat disimpulkan. Maka perlu dilakukan uji formal melalui uji Breusch-Godfrey (BG). Uji ini dikenal dengan Lagrange Multiplier test (LM test). Hasil empiris dari uji LM dapat dilihat pada Tabel 5 sebagai berikut :

\section{Tabel 6}

Hasil Uji Autokorelasi Metode Breusch-Godfrey

Breusch-Godfrey Serial Correlation LM Test:

\begin{tabular}{cccc}
\hline \hline F-statistic & 0.807862 & Prob. F(2,14) & 0.4655 \\
Obs*R-squared & 2.069355 & Prob. Chi-Square(2) & 0.3553 \\
\hline \hline
\end{tabular}

Sumber : Data diolah (Eviews) 
Berdasarkan hasil empiris pada tabel 6 di atas nilai probabilitas chi-squares lebih besar dari nilai $\alpha=0,05$. Maka hipotesis nol (Ho) tidak dapat ditolak, menunjukkan penelitian ini tidak mengandung autokorelasi.

\section{Hasil Uji Statistik \\ Hasil Uji Simultan (Uji F)}

\begin{tabular}{|c|c|c|c|c|}
\hline \multicolumn{5}{|c|}{$\begin{array}{c}\text { Tabel } 7 \\
\text { Haictil }\end{array}$} \\
\hline Variable & Coefficient & $\begin{array}{c}\text { Std. } \\
\text { Error }\end{array}$ & $\begin{array}{c}\mathbf{t}- \\
\text { Statistic } \\
\end{array}$ & Prob. \\
\hline C & 0.932248 & 0.944978 & 0.986529 & 0.3386 \\
\hline $\mathrm{D}(\mathrm{E})$ & 0.274263 & 0.130157 & 2.107170 & 0.0512 \\
\hline D(LnPDB) & -8.198015 & 2.445327 & 3.352523 & 0.0040 \\
\hline ECT(-1) & -0.728967 & 0.188955 & 3.804954 & 0.0016 \\
\hline F-statistic & 10.58196 & Prob(F-sta & tistic) & 0.000445 \\
\hline
\end{tabular}

Dari tabel 7 menunjukkan nilai $\mathrm{F}$ statistik adalah 10.58196 dengan probabilitas statistik sebesar 0.000445 lebih kecil dari $\alpha=0,05$ sehingga ini menunjukkan bahwa secara simultan semua variabel independen yaitu kurs dan produk domestik bruto, serta Error Correction Term (ECT) berpengaruh signifikan terhadap neraca transaksi berjalan di Indonesia.

\section{Hasil Uji Parsial (Uji t)}

Hasil pengujian secara parsial (uji t) dapat dilihat pada tabel 7 di atas, hasil ini memperlihatkan dari 2 (dua) variabel independen yang diteliti hanya 1 (satu) variabel yang berpengaruh signifikan terhadap neraca transaksi berjalan di Indonesia yaitu variabel kurs. Ini dapat dilihat melalui nilai probabilitas statistik lebih kecil dari $\alpha=0,05$. Sedangkan variabel produk domestik bruto tidak mempengaruhi neraca transaksi berjalan di Indonesia.

\section{Koefisien Determinasi $\left(\mathbf{R}^{2}\right)$}

Hasil empiris menunjukkan untuk estimasi output persamaan regresi melalui metode ECM, diperoleh nilai R-squared sebesar 0.664893 dan nilai Adjusted R-squared sebesar 0.602060. Dalam penelitian ini nilai koefisien determinasi $\left(\mathrm{R}^{2}\right)$ yang digunakan nilai $\mathrm{R}-$ squared sebesar 0.664893 . Maka variasi variabel kurs dan produk domestik bruto mampu dijelaskan sebesar $66,48 \%$ variasi variabel neraca transaksi berjalan di Indonesia sedangkan sisanya 33,52\% yang dijelaskan oleh variabel-variabel di luar penelitian ini.

\section{SIMPULAN}

Hasil estimasi yang diperoleh secara parsial dari penelitian ini bahwa variabel produk domestik bruto berpengaruh negatif dan signifikan sedangkan kurs berpengaruh negatif namun tidak signifikan terhadap neraca transaksi berjalan di Indonesia.

Hasil estimasi dalam penelitian ini secara simultan variabel kurs dan produk domestik bruto berpengaruh terhadap neraca transaksi berjalan di Indonesia.

Nilai koefisien yang menjelaskan variabel neraca transaksi berjalan yang terbesar adalah produk domestik bruto kemudian kurs. 
Pemerintah diharapkan supaya menjaga nilai mata uang rupiah terhadap mata uang asing supaya perekonomian lebih stabil dengan menerapkan kebijakan devaluasi nilai tukar.

Pemerintah diharapkan menjaga pertumbuhan ekonomi dengan mendorong masyarakat dalam berwirausaha sehingga perekonomian nasional mengalami peningkatan.

\section{DAFTAR PUSTAKA}

Amzar2, B. N. E. Y. V. (2017). Pengaruh harga CPO, harga minyak mentah dunia, harga karet dunia dan kurs terhadap defisit neraca transaksi berjalan Indonesia. Jurnal Paradigma Ekonomika.

Ariyani, N., Priyanto, F. W., \& Yuliati, L. (2018). Current account determinants in ASEAN 6. Journal of Economics, Business \& Accountancy Ventura. https://doi.org/10.14414/jebav.v21i2.1419

Asmarani, T. E. (2015). The Persistency And The Sustainability Of The Indonesia's Current Account Deficit. Buletin Ekonomi Moneter Dan Perbankan. https://doi.org/10.21098/bemp.v17i3.35

Clower, E., \& Ito, H. (2012). The Persistence of Current Account Balances and its Determinants: The Implications for Global Rebalancing. SSRN Electronic Journal. https://doi.org/10.2139/ssrn.2190266

Fazil KAYIKÇI. (2012). Determinants of the current account balance in Turkey: Vector auto regression (VAR) approach. African Journal Of Business Management. https://doi.org/10.5897/ajbm11.1788

Handoko, R. (2015). Determinan Neraca Transaksi Berjalan Di Indonesia: Pendekatan Vektor Autoregresif. Kajian Ekonomi Dan Keuangan.

Hung, J. H., \& Gamber, E. N. (2010). An absorption approach to modeling the us current account. Review of International Economics. https://doi.org/10.1111/j.14679396.2010.00867.x

Saputra, T., \& Maryatmo, R. (2016). Pengaruh Nilai Tukar dan Suku Bunga Acuan Terhadap Neraca Transaksi Berjalan di Indonesia Periode 2005:1 - 2015: 1 (Pendekatan Error Correction Model). https://doi.org/10.24002/modus.v28i1.668

Wijaya, E. (2019). Kondisi Makroekonomi Sebagai Faktor Yang Mempengaruhi Neraca Transaksi Berjalan Periode 1999-2016. Ekspansi: Jurnal Ekonomi, Keuangan, Perbankan Dan Akuntansi. https://doi.org/10.35313/ekspansi.v11i1.1247 